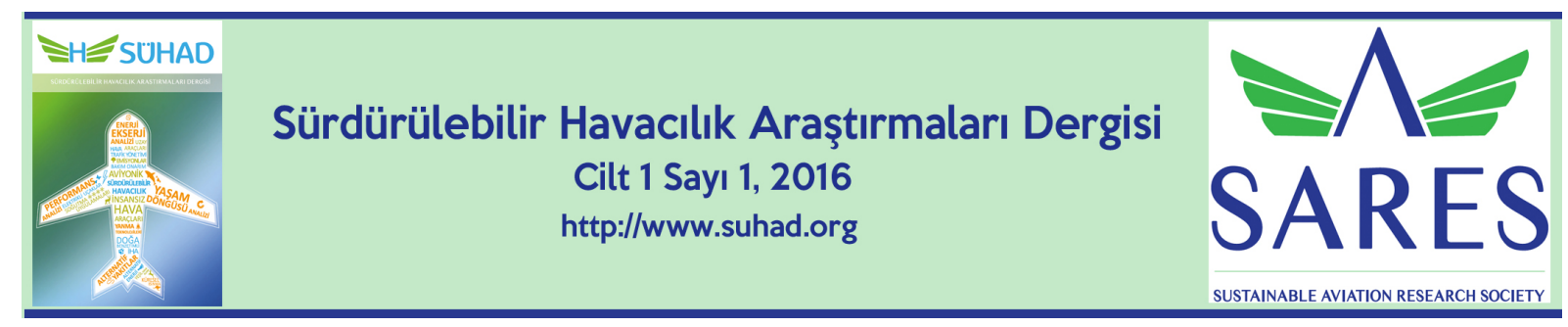

\title{
EDITTÖR YAZISI
}

\section{T. Hikmet KARAKOÇ}

Havacılık ve Uzay Bilimleri Fakültesi, Anadolu Üniversitesi, Eskişehir, hikmetkarakoc@gmail.com

DOI: 10.23890/SUHAD.2016.0102

Değerli Okurlar,

Bilindiği gibi havacılık ülkemizde her geçen gün önem kazanan bir konu olup, sektör olarak da hızla büyümektedir. Bu kadar hızlı gelişmekte olan bu sektörde büyüme ve aşama kaydetmek kadar sürdürülebilirliği sağlamak da büyük önem taşımaktadır. Temel olarak bu düşünce ve havacılıkta sürdürülebilirliği sağlanması felsefesiyle kurulmuş olan Sürdürülebilir Havacılık Araştırmaları Derneği (SARES), havacılık konuları üzerine çalışmalar yürüten profesyonellerin ve akademisyenlerin bir araya gelmesi ve kamuoyunun bilinçlenmesi amaciyla 2016 yılından itibaren Sürdürülebilir Havacılık Araştırmaları Dergisi (SÜHAD)'ni yayımlama kararı almıştır. Yılda iki sayı olarak yayımlanacak olan Sürdürülebilir Havacılık Araştırmaları Dergisi'nde aşağıdaki konulara yer verilecektir:

- Sürdürülebilir Hava ve Uzay Araçları

○ Sürdürülebilir uçak, helikopter, füze, fırlatma ve uydular tasarımı, teknolojik değişim, yenilik, araştırma ve geliştirme

○ Matematiksel modelleme, sayısal / deneysel yöntemler, optimizasyon

- Yeşil uçaklar

- Yeşil havayolları

- Yeşil havaalanları

- Yeşil motor

- Yeşil havacılık araçları

- Elektrikli Uçaklar

- Daha Elektrikli Uçaklar (More Electric Aircraft)

- Tümü Elektrikli Uçaklar (All Electric Aircraft)

- Yenilenebilir enerji kaynakları;

- Alternatif / yeşil havacılık yakıtları

- Enerji geri kazanım sistemleri, alternatif / yenilenebilir / temiz enerji teknolojileri

○ Yaşam döngüsü tasarımı ve yaşam döngüsü değerlendirmesi; maliyet verimliliği; atık / geri dönüşüm

○ Emisyon / gürültü / radyasyon, küresel 1sınma / iklim değişikliği: Çevre etkileri ve ölçüm teknikleri

○ Matematiksel modelleme, sayisal / deneysel yöntemler, optimizasyon

- Uçaklarda Klima ve soğutma uygulamaları

- Hava meydanlarında iklimlendirme ve optimizasyon

- Alternatif soğutucu akışkan uygulamaları

- Enerji, ekserji, performans analizi, uçuş mekaniği ve hesaplamalı akışkanlar dinamiği

○ Enerji analizleri

- Ekserji analizleri

- Performans analizi

- Uçuş mekaniği

- Hesaplamalı akışkanlar dinamiği

- Havacılık araçları için motor tahrik teknolojileri

- Yanma teknolojileri

- Yanma ve optimizasyon

- Yanma kararsızlıkları

- Yenilikçi yanma teknolojileri

- Matematiksel modelleme, sayısal / deneysel yöntemler, optimizasyon 
- Aviyonik ve oto kontrolü

○ Aviyonik

- Otomatik Kontrol

- Uzay araç malzemeleri, ölçüm teknikleri ve sensörler

- Tasarım, yönetim, planlama, geliştirme

- Uzay araç stratejik planlama, hükümet mevzuat, politika yapma

- Havacılık yönetimi, filo planlama / çizelgeleme; hava trafik yönetimi; Gelecekteki hava taşımacılığı

- Havaalanı tasarım, yönetim, planlama, geliştirme

- Uçak bakım, onarım ve revizyon; uçuşa elverişlilik, güvenilirlik / güvenlik

Sürdürülebilir Havacılık Araştırmaları Dergisi'nin kısa zamanda ulusal ve uluslararası veri tabanları ve indekslerde taranan bir dergi ve havacılık alanında yol gösterici olma hedefi bulunmaktadır. Uluslararası alanda tanınan tüm önde gelen dergiler gibi, Sürdürülebilir Havacılık Araştırmaları Dergisi de bir CrossRef üyesi olup, her bir yayına özgü dijital nesne kimliği (DOI) vermektedir.

Sürdürülebilir Havacılık Araştırmaları Dergisi’nin yayımlanmasında emeği geçen Sürdürülebilir Havacılık Araştırmaları Derneği Yönetim Kurulu'na, Sürdürülebilir Havacılık Araştırmaları Dergisi Editör Kurulu'na, katkılarından ötürü ilk sayımızda yazıları yer alan tüm yazarlara ve bu yazıların incelemesini yapan hakemlere teşekkür ederim.

Saygilarımla. 